\title{
Water Regulation Ecosystem Services Following Gap Formation in Fir-Beech Forests in the Dinaric Karst
}

\author{
Urša Vilhar $\mathbb{D}$
}

check for

updates

Citation: Vilhar, U. Water Regulation Ecosystem Services Following Gap Formation in Fir-Beech Forests in the Dinaric Karst. Forests 2021, 12, 224. https://doi.org/10.3390/f12020224

Academic Editor:

Thomas Cordonnier

Received: 19 November 2020

Accepted: 11 February 2021

Published: 16 February 2021

Publisher's Note: MDPI stays neutral with regard to jurisdictional claims in published maps and institutional affiliations.

Copyright: (C) 2021 by the author. Licensee MDPI, Basel, Switzerland. This article is an open access article distributed under the terms and conditions of the Creative Commons Attribution (CC BY) license (https:// creativecommons.org/licenses/by/ $4.0 /)$.
Department of Forest Ecology, Slovenian Forestry Institute, Večna pot 2, SI-1000 Ljubljana, Slovenia; ursa.vilhar@gozdis.si; Tel.: +386-(0)1-200-78-46

\begin{abstract}
This paper investigates how variation in forest structural characteristics affects the water retention capacity of gaps and forests in fir-beech forests in the Dinaric Karst. Forests are identified as a key element of the landscape for provision of pristine water resources, particularly in highly vulnerable karst aquifers characterized by rapid infiltration of recharge water, high subsurface permeability, and heterogeneous underground flow. Indicators of hydrologic fluxes (drainage flux, canopy interception, transpiration, and soil evaporation) in a large experimental gap (approximately 0.2 ha in size) and those in a nearby old-growth gap were compared over a 13-year period using the Brook90 hydrological model and their structural characteristics were analyzed. In addition, the hydrologic fluxes were also simulated for a managed forest and an old-growth forest for reference. Water regulation capacity was lowest in the experimental gap, where drainage flux accounted for $81 \%$ of precipitation and the sum of canopy interception, transpiration, and soil evaporation (evapotranspiration) accounted for $18 \%$. This was followed by the old-growth gap, where drainage flux accounted for $78 \%$ of precipitation and evapotranspiration for $23 \%$. Water retention capacity was highest and generally similar for both forests, where $71-72 \%$ of annual precipitation drained to the subsurface. The results of this study suggest that the creation of large canopy gaps in fir-beech forests in the Dinaric Karst results in significant and long-lasting reduction in soil and vegetation water retention capacity due to unfavorable conditions for successful natural tree regeneration. For optimal provision of water regulation ecosystem services of forests in the Dinaric Karst, small, irregularly shaped canopy gaps no larger than tree height should be created, mimicking the structural characteristics of naturally occurring gaps in old-growth forests.
\end{abstract}

Keywords: water retention capacity; drainage flux; evapotranspiration; Brook90 hydrological model; experimental canopy gap; old-growth forest

\section{Introduction}

Through their ecosystem services (ES), forests are identified as a key element of the landscape for provision of pristine water resources, especially in karst ecosystems [1]. ES are broadly defined as the benefits that humans receive from natural ecological processes [2,3], which are generally divided into provisioning, regulating, supporting, and cultural services [4]. Water regulation ES refer to the regulation of hydrologic flows [5,6] and are derived from the relationships between input (precipitation) and output (drainage fluxes). Water regulation ES of forests depend on development stage and structure $[7,8]$, management interventions (managed vs. unmanaged) [9], and edaphic factors [10].

Scientists have repeatedly highlighted the link between the recent rapid loss of forest cover and the reduced water regulation capacity of forest ecosystems [11,12], increased erosion [13], and more destructive flooding, causing hazards and ecological problems as well as economic losses, especially in mountainous regions [14]. However, the effects of management measures on the water retention capacity of forests in gap-based silviculture have been poorly studied $[15,16]$. Moreover, there is little information on how water regulation ES of forests are affected after canopy release in karst aquifers, with their hydrogeological 
characteristics $[1,17,18]$. Carbonate rocks, from which karst systems typically develop, cover an estimated $14 \%$ to $29 \%$ of the land area in Europe and $10 \%$ to $15 \%$ worldwide [19]. Karst aquifers provide $25 \%$ of the freshwater for human consumption worldwide and $40 \%$ in the USA [20]. Karst hydrology is generally characterized by rapid infiltration of recharge water, high permeability of the subsurface, and heterogeneous underground flow along karst channels toward springs [21,22]. Due to their unique hydrogeological characteristics, karst aquifers are particularly sensitive to human activities [23,24] and suffer from rocky desertification, especially in semi-humid and humid climates, involving damage to surface vegetation, soil erosion, and extensive bedrock exposure [25,26]. Forest soils in karst areas are typically shallow or absent, resulting in limited water storage, and nutrient cycling is limited to that between the surface organic layer and vegetation $[27,28]$. To minimize the negative effects of forest management on ecological processes in karst aquifers, there is a long tradition of sustainable forest management, systematic silvicultural planning, and more recently the development of close-to-nature management [29] in Dinaric Karst forests. The creation of canopy gaps by removing only a small group of trees or the traditional irregular shelterwood system sensu Matthews [30] has been applied in the region to mimic as closely as possible the natural disturbance regimes and structural characteristics of old-growth forests [31], with unevenly aged and horizontally and vertically structured forest $[29,32,33]$, as opposed to conventional clearcutting, which involves harvesting large areas of forest [34,35]. However, due to socio-economic changes in recent decades, a shift towards larger canopy gaps has been promoted as more convenient for forest management and to promote valuable tree species (e.g., sycamore maple) in the Dinaric Karst [31,36]. Nevertheless, large canopy gaps with diameters greater than the height of the surrounding forest can significantly alter the water regulating the capacity of vegetation [37].

In 2001 several experimental canopy gaps of different sizes (small-medium-large) were established within the EU FP5 project Nat-Man. This experiment provided a unique opportunity to compare microclimatic conditions [38,39], edaphic factors [40,41], aboveground [42] and below-ground diversity [43,44], natural regeneration patterns [45-47], and hydrological processes $[37,48-50]$ in experimental canopy gaps compared to a gap in a nearby old-growth forest remnant Rajhenavski Rog. Previous studies have shown that dense natural tree regeneration occurred in small- and medium-sized gaps four years after gap formation [47] and hydrologic fluxes were comparable to those in old-growth gap [49]. However, the large experimental gap (approximately 0.2 ha in size) was the only one in which natural tree regeneration was not successfully established even 12 years after gap formation. The diameter of the experimental gap was larger than the height of the surrounding forest and was much larger compared to small canopy gaps [47] in traditional irregular shelterwood managed forests in the Dinaric Karst.

The aim of our study was to investigate how variation in forest structure characteristics affects the water retention capacity of gaps and forests in fir-beech forests in the Dinaric Karst. Specifically, the water retention capacity of vegetation and soil in the large experimental gap was compared to a gap in a nearby old-growth forest as an ideal of close-to-nature management. In addition, the water retention capacity of a managed forest and an old-growth forest and their structural characteristics were compared for reference.

Karst aquifers are unique because, unlike other aquifers, they are characterized by a threefold permeability: a. matrix porosity due to pore spaces, formed within the rocks by constitutive minerals (sub-millimeter scale); b. secondary or fracture porosity formed by orogenic processes (millimeter scale), and c. tertiary or conduit porosity where cavities and integrated conduits are formed by chemical dissolution, which is a characteristic feature of karst areas [51]. Soil water fluxes in karst areas are therefore very complex [18], and hydrologic fluxes are often estimated by eddy covariance [52-54], tree sap flow measurements [55-58], or simulated by hydrological models [37,48,59-64]. In our study, the Brook90 hydrological model was used to simulate indicators of hydrologic fluxes (drainage flux-DF; canopy interception-I; transpiration-TRAN and soil evaporation-SE) in gaps and forests over a 13-year period. Water retention capacity is derived from the relationships 
between input (precipitation; P) and output (drainage fluxes; DF). Sites with the lowest DF estimates and the highest sum of I, TRAN, and SE relative to P, often referred to as ecosystem evapotranspiration (ETP) [65], are assumed to have higher water regulation capacity.

Results of this study could have beneficial implication in hydrologically oriented forest management measures [8] for optimized provision of water regulation ES in karst aquifers $[66,67]$.

\section{Materials and Methods}

\subsection{Study Sites}

The old-growth and managed fir-beech forests studied are located in the northern part of the Dinaric Alps in southeastern Slovenia $\left(45^{\circ} 20^{\prime} \mathrm{N}, 14^{\circ} 30^{\prime} \mathrm{E}, 860-890 \mathrm{~m}\right.$ a.s.l.). The diverse topography of this high karst plateau is characterized by numerous sinkholes, ridges, and slopes. The bedrock is Cretaceous limestone and the soils are shallow, welldrained Eutric Cambisols and Rendzic Leptosols [40]. The climate of the region is montane with annual precipitation up to $1600 \mathrm{~mm}$. The long-term (1961-1990) mean annual air temperature measured at the nearest meteorological station (Kočevje, $45^{\circ} 39^{\prime} \mathrm{N}, 14^{\circ} 51^{\prime} \mathrm{E}$, $467 \mathrm{~m}$ a.s.l.) is $8.3^{\circ} \mathrm{C}$, which corresponds to a temperature of $5.9^{\circ} \mathrm{C}$ at the study site (using an environmental lapse rate of $6^{\circ} \mathrm{C}$ per $\mathrm{km}$ ).

The specific old-growth Dinaric fir-beech forest Rajhenavski Rog was defined as a secondary virgin forest and officially declared as an old-growth forest in the first forest management plan of the area in 1892 [68]. It has a complex structure, being a mosaic of different forest development phases (optimal, terminal, declining, juvenile development phase [69], including standing dead trees, fallen logs, stumps, and roots [70] in different stages of decay of coarse woody debris [71]. The forest where the study was conducted was classified as Omphalodo-Fagetum association [72] and had a stem volume of $746 \mathrm{~m}^{3} \mathrm{ha}^{-1}$ and total basal area of $49 \mathrm{~m}^{2} \mathrm{ha}^{-1}$ in 2006 [73]. About $68 \%$ of the stem volume includes European beech (F. sylvatica L.) and 32\% silver fir (Abies alba Mill.). Norway spruce (Picea abies (L.) Karst.), sycamore maple (Acer pseudoplatanus L.), elm (Ulmus glabra Huds.), and lime (Tilia cordata Mill.) comprise less than $1 \%$ of the total stem volume. The site faces south, has a slope of $10 \%$ and the predominant soil units are Eutric Cambisols and Rendzic Leptosols [74,75]. The average thickness of the $\mathrm{O}$ horizon is $3.4 \mathrm{~cm}$ (with standard deviation of $1.1 \mathrm{~cm}$ ), the A horizon is $10.3 \mathrm{~cm}$ (with standard deviation of $4.7 \mathrm{~cm}$ ), and the B horizon is $35.2 \mathrm{~cm}$ (with standard deviation of $6.4 \mathrm{~cm}$ ). In the old-growth forest, a part of the stand and an irregularly shaped canopy gap (approximately 0.07 ha in size), which occurred naturally in the winter of 2002-2003 after windthrow, were used as study sites (Table 1). The canopy gap in the old-growth forest contained patches of different development phases, including dense natural beech regeneration. 
Table 1. General characteristics of the study sites and soil.

\begin{tabular}{|c|c|c|c|c|c|c|c|c|c|c|c|c|c|c|}
\hline Study Site & & $\begin{array}{c}\text { Year of } \\
\text { Creation }\end{array}$ & $\begin{array}{c}\text { Shape and } \\
\text { Dimensions } \\
\left(\mathrm{m}^{2}\right)\end{array}$ & $\begin{array}{l}\text { Harvesting } \\
\text { Method }\end{array}$ & $\begin{array}{l}\text { Elevation } \\
\text { (m a.s.l.) }\end{array}$ & Slope (\%) & Aspect & $\begin{array}{c}\text { Average } \\
\text { Tree Height } \\
\text { (m) } \\
2001^{2 / 2013^{3}} \\
\end{array}$ & $\begin{array}{c}\text { Average } \\
\text { Diameter at } \\
\text { Breast Height }{ }^{1} \\
(\mathrm{~cm})\end{array}$ & $\begin{array}{c}\text { Stem } \\
\text { Volume }^{1} \\
\left(\mathrm{~m}^{3} \mathbf{h a}^{-1}\right)\end{array}$ & $\begin{array}{c}\text { Ground } \\
\text { Vegetation } \\
\text { Cover (\%) } \\
2001^{2} / 2013^{3}\end{array}$ & $\begin{array}{l}\text { Soil Depth }{ }^{4} \\
\text { (cm) }\end{array}$ & $\begin{array}{c}\text { Stoniness }{ }^{4} \\
(\% \text { vol })\end{array}$ & $\begin{array}{l}\text { Soil Texture } \\
\text { Class }^{4}\end{array}$ \\
\hline Managed & forest & - & - & $\begin{array}{l}\text { Thinning as } \\
\text { part of an } \\
\text { irregular } \\
\text { shelterwood } \\
\text { manage- } \\
\text { ment } \\
\text { system }\end{array}$ & 860 & 10 & south-east & 20 & $10-45$ & 255 & $20 / 21$ & 32.2 & 24.4 & Loam \\
\hline Experimental & gap & $\begin{array}{c}\text { Winter } \\
\text { 2000/2001 }\end{array}$ & $\begin{array}{l}\text { Near circular, } \\
2375\end{array}$ & $\begin{array}{l}\text { Experimental } \\
\text { clear-cut }\end{array}$ & 860 & 15 & south-east & $0.1 / 0.5$ & $<10$ & - & $5.5 / 20$ & 31.3 & 22.3 & Loam \\
\hline Old growth & forest & - & - & - & 880 & 10 & south-east & 27 & $41-50$ & 746 & $22 / 24$ & 32.6 & 29.7 & Clay loam \\
\hline Old growth & gap & $\begin{array}{c}\text { Winter } \\
2002 / 2003\end{array}$ & Irregular, 710 & Windstorms & 880 & 10 & south-east & $0.5 / 2.0$ & $<10$ & - & $62 / 100$ & 29.9 & 23.1 & Clay loam \\
\hline
\end{tabular}

Notes: ${ }^{1}$ Measured in 2006 for forest department $[73,76] ;{ }^{2}[47] ;{ }^{3}[50] ;{ }^{4}$ Average value for soil profile $[42,49]$. 
The specific managed Dinaric fir-beech forest is located nearby, at a distance of about $1300 \mathrm{~m}$, and has similar elevation, aspect and slope. The predominant soils are also Eutric Cambisols and Rendzic Leptosols. The average thickness of the O horizon is $3.3 \mathrm{~cm}$ (with standard deviation of $1.3 \mathrm{~cm}$ ), that of the A horizon is $16.2 \mathrm{~cm}$ (with standard deviation of $4.0 \mathrm{~cm}$ ), and that of the B horizon is $23.6 \mathrm{~cm}$ (with standard deviation of $7.1 \mathrm{~cm}$ ). In managed and old-growth forests about $30 \%$ of the area is bare limestone rock. Up to $40 \mathrm{~cm}$ of organic matter may be accumulated in holes and cracks. Similar to the old-growth forest, the managed forest was classified as Omphalodo-Fagetum association [72] and is dominated by European beech with $56 \%$ of the stem volume and silver fir with $34 \%$. The rest of the stem volume consists of sycamore maple. A long tradition of sustainable forest management, systematic silvicultural planning, and more recently the development of close-to-nature management [29], with the idea of mimicking natural disturbance regimes and forest dynamics as closely as possible [31], have led to the relatively preserved vegetation composition of these forests [36]. They are traditionally managed with an irregular shelterwood system sensu Mathews [30], in which small canopy gaps are gradually increased and successful natural regeneration of European beech, sycamore maple, and silver fir in mixed forests is encouraged to ensure continuous forest cover and minimize soil degradation [47].

In the managed forest, a closed uneven-aged stand was selected and an irregular experimental clearcut gap (approximately 0.2 ha in size) was established in the winter of 2000-2001, as part of the EU FP5 project Nat-Man. All the trees in the large experimental gap were harvested and carefully removed by horse skidding. The ground vegetation was sparse and no higher than $0.1 \mathrm{~m}$ after gap formation. The large experimental gap was selected for this study because it was the only canopy gap where natural regeneration was not successfully established even 12 years after gap formation. Further details on the selected sites are presented in Table 1.

\subsection{Indicators for Water Regulation ES}

The water regulation capacity of gaps and forests was assessed by comparing indicators of hydrologic fluxes relative to precipitation in the open $(\mathrm{P})$ using the water balance equation:

$$
\mathrm{P}=\mathrm{DF}-\mathrm{I}-\mathrm{TRAN}-\mathrm{SE} \pm \Delta \mathrm{SWC}
$$

where $\mathrm{P}$ is precipitation in the open; DF refers to all forms of drainage or runoff, e.g., unsaturated flow and saturated flow through the soil matrix and macropores; I is evaporation from wet canopy surfaces, such as intercepted water, TRAN is transpiration from the canopy and understory vegetation, and SE is evaporation from the ground or soil evaporation (SE). The sum of I, TRAN, and SE is often referred to as ecosystem evapotranspiration (ETP) [65]. SWC refers to soil water content and $\triangle S W C$ is the variation in soil water content, assumed to yield 0 in the long run. These hydrological indicators were simulated for each study site using the Brook90 water balance model [77,78] over a 13-year period from 2001 to 2013, except for the old-growth gap, for which the simulation ran from 2003 to 2013.

\subsection{Meteorological Data and Soil Hydrological Measurements}

Meteorological data were collected above the tree canopy using an automated weather station (Vantage Pro ${ }^{\circledR}$ wireless, Davis Instruments, Hayward, CA, USA). Hourly mean air temperature and humidity, wind direction and speed, and hourly totals of precipitation were recorded [48]. Missing air temperature and humidity data were substituted with data from the Kočevje meteorological station and missing global radiation data were replaced with data from the Iskrba EMEP station (Environmental Agency of the Republic of Slovenia archives) using site-specific regression functions [39]. From 2001 to 2007, monthly or biweekly throughfall (the amount of precipitation that is not intercepted by vegetation and reaches the forest floor) was recorded in forests and gaps at a height of $1.3 \mathrm{~m}$ using a series of nine funnel collectors $\left(240 \mathrm{~cm}^{2}\right.$ each) arranged along a regular grid with $5 \times 5 \mathrm{~m}$ spacing. Incidental precipitation was recorded monthly from 2001 to 2007 in an open field near the 
study sites using the same type of funnel collectors. Data sets from 2003 to 2007 were used for the old-growth gap, that occurred naturally during the winter of 2002-2003.

Using representative soil samples from the predominant soil units, the available water capacity of the mineral soil horizons was calculated for each study site from pressure plate measurements of field capacity (soil water content at $0.033 \mathrm{MPa}$ ). The permanent wilting point (soil water content at $1.5 \mathrm{MPa}$ ) and hydraulic conductivity of the saturated soil were also determined. The average soil thickness at all sites was $40 \mathrm{~cm}$, and this depth was assumed to be the rooting depth for all sites. Soil water content (SWC) of the 0- to 40-cm layer was measured monthly at three locations in each site in 2003 and twice monthly in 2004 using time-domain reflectometry (TDR, Prenart Equipment, Frederiksberg, Denmark). Double probes were installed vertically and extended through the 40-cm layer, including the organic layer. Soil-specific calibration curves for vertical TDR probes were used, obtained by the calibration procedures described in Dirksen [79]. SWC was determined once a month in 2001 and 2002 by collecting three replicate volumetric soil samples at 10, 20, and $40 \mathrm{~cm}$ depths at each site and measuring weight loss after oven-drying the samples at $105{ }^{\circ} \mathrm{C}$ for $24 \mathrm{~h}$. Volumetric water contents were converted to water depths (mm) by multiplying the values by the thickness of the soil layer and correcting for stone content.

\subsection{The Brook90 Hydrological Model}

The Brook90 model was chosen since it was found to be suitable for simulating hydrologic fluxes of stands and gaps in strongly structured forest ecosystems, complex karst morphology, and heterogeneous forest soils with small soil water storage capacity in previous studies $[48,49]$. However, the model is capable to deal with a dual permeability system [80], whereas a threefold permeability system cannot be represented by this model. The model calculates daily water fluxes (tree transpiration, canopy interception, throughfall, soil evaporation, snow evaporation, drainage (or runoff)) and soil water content at different depths or for the whole rooting depth. Tree transpiration and soil evaporation are calculated separately using the Shuttleworth-Wallace method [81], modified to separate evaporation during the day from evaporation during the night [77]. An important feature of the Brook 90 model is that it only considers homogeneous plant cover at a selected site or catchment. Therefore, differentiation between forests, gaps, and regeneration stage was achieved through measured or preset input parameters corresponding to different cover type, plant height and density, leaf area index, interception, and other ecophysiological characteristics. More information on model parametrization can be found in $[48,49]$.

\subsection{Model Fitting and Testing}

Site-specific parameters for running the Brook 90 model (see Table S1) were derived by fitting model output with measured monthly throughfall data for managed and old-growth forests collected from 2001-2003 and tested with the throughfall data from 2004-2007. An additional model fit was performed for each site by comparing simulated and measured daily soil water contents of the rooting zone (corrected for stone content) with the data sets for 2001-2004 and testing with data sets for 2005-2007. For the old-growth gap data sets from 2003-2004 were used for model fitting and data sets from 2005-2007 were used for model testing.

The goodness of fit was assessed by examining the linear correlation coefficient $(\mathrm{r})$, which describes the degree of correspondence between measured and simulated values, the index of agreement (D) [82], which is a descriptive measure of relative error, and the root mean square error (RMSE), which expresses the error between the measured and simulated values (ibid.).

\subsection{Statistical Analyses}

Spearman's rank correlation coefficients $(R)$ were used to evaluate the relationships between annual indicators of hydrologic fluxes (DF, SE, TRAN, and I) for gaps and forests. The nonparametric Kruskal-Wallis test was used to test for differences in annual DF, SE, 
TRAN, and I estimates among the four study sites, with estimates matched by simulation year. The Wilcoxon signed-rank test with Holm's correction was used for post hoc multiple comparison tests between the study sites. GraphpadPrism ${ }^{\circledR}$ version 6.04, GraphPad Software MacKiev: La Jolla California USA, 2014. was used to perform the statistical analysis.

\section{Results}

Weather data showed considerable interannual variation from 2001 to 2013 (Figure 1). The annual P was lower than the long-term P (1971-2000) in $2003(-22 \%)$ and $2011(-30 \%)$, when the difference between P and reference evapotranspiration (Ref ETP) also indicated the highest water deficit (-63\% in 2011 and $-50 \%$ in 2003 compared to the long-term annual mean). This corresponds with the extreme drought conditions in summer 2003 as reported by several authors [83-87], which led to widespread disturbances in European forest ecosystems. P above the long-term annual mean was measured in $2004(+11 \%)$ and $2010(+17 \%)$, when the difference between P and Ref ETP also indicated the highest water surplus ( $+33 \%$ in 2004 and $+50 \%$ in 2010). Mean annual air temperature was not as variable as annual P. Only in 2002 and 2007 were mean annual air temperatures higher than the long-term annual mean.
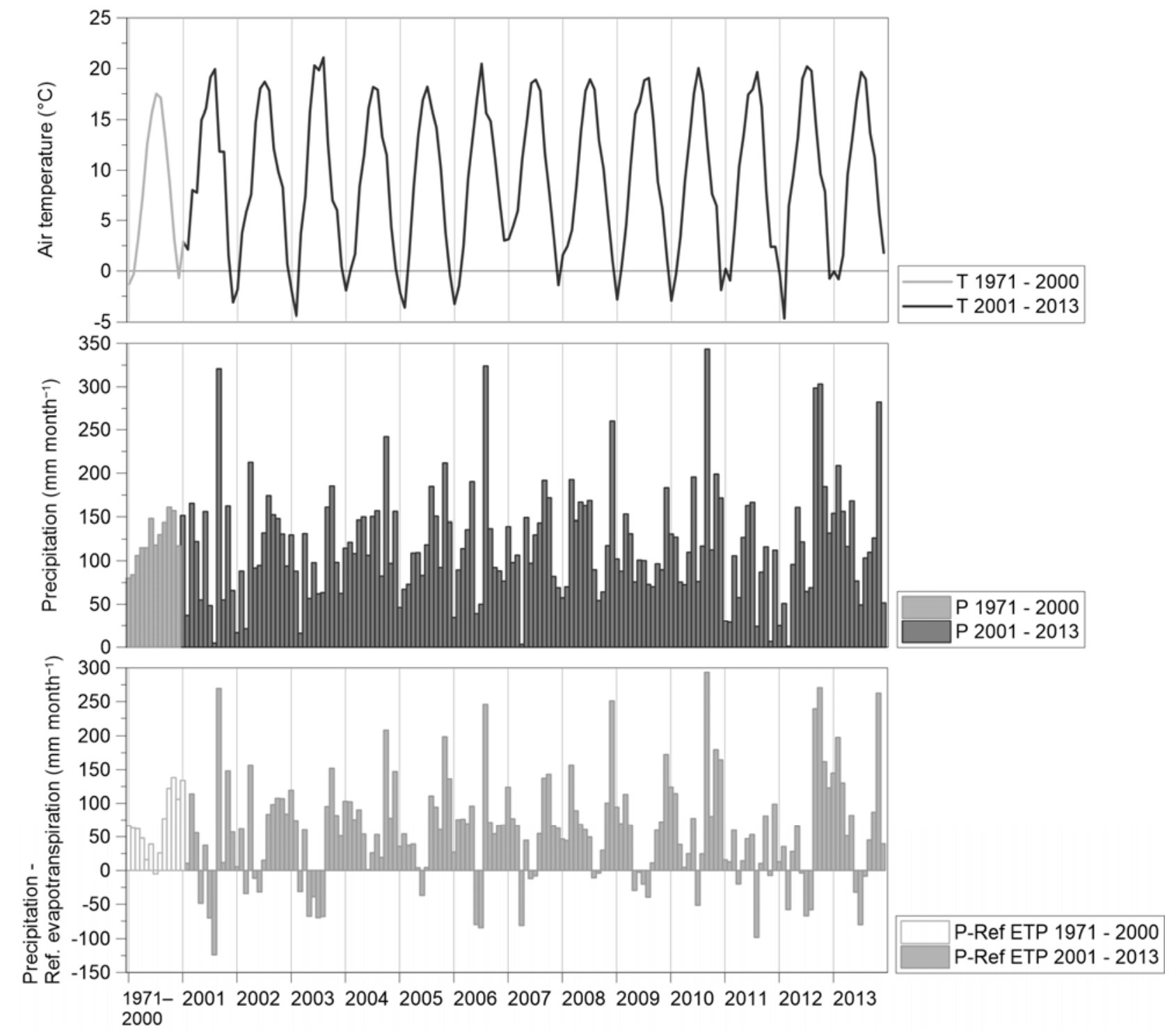

T $2001-2013$

Figure 1. Mean monthly air temperature $(\mathrm{T})$, precipitation $(\mathrm{P})$, and difference between $\mathrm{P}$ and reference evapotranspiration (P-Ref ETP) at Kočevje meteorological station from 1971 to 2000 (first column) and from 2001 to 2013. 


\subsection{Model Fitting and Testing}

Table S1 summarizes the input parameters used in the Brook90 model simulations. Monthly throughfall (Figure S1) and daily soil water contents (Figure S2) were well simulated in both time and magnitude for all sites). For throughfall fitting, the average $\mathrm{D}$ was 0.772 and average RMSE was $60.2 \mathrm{~mm} \mathrm{month}^{-1}$. For model testing, the average $\mathrm{D}$ was 0.772 and average RMSE was $60.2 \mathrm{~mm}$ month $^{-1}$ (Table S2). Throughfall measurements were limited for financial reasons to monthly or biweekly recordings using a series of nine funnel collectors $\left(240 \mathrm{~cm}^{2}\right.$ each) arranged along a regular grid with $5 \mathrm{~m} \times 5 \mathrm{~m}$ spacing. Mean deviation of recorded throughfall quantities was $5 \%$ in the managed forest and ranged between $-6 \%$ and $21 \%$. In the old-growth forest mean deviation was $10 \%$ and ranged between $-12 \%$ and $22 \%$. In the old-growth gap, mean deviation of recorded throughfall quantities was $6 \%$ and ranged between $-16 \%$ and $17 \%$, respectively. In the experimental gap, mean deviation of recorded throughfall quantities was only $2 \%$ and ranged between $-4 \%$ and $19 \%$. To cover throughfall variability and assure spatial representativeness, a higher number of throughfall collectors is recommended [88], e.g., 35 to 40 collectors for heterogeneous uneven-aged single species and mixed forest of two or more tree species, with small canopy gaps or even more than 40 collectors in case of big canopy gaps. For soil water content fitting, the average D was 0.865 and the average RMSE was $13.0 \mathrm{~mm}$ day $^{-1}$. For model testing, the average D was 0.750 and the average RMSE was $15.6 \mathrm{~mm}$ day $^{-1}$ (Table S2).

\subsection{Indicators of Water Regulation Ecosystem Services (ES)}

Annual DF estimates followed the pattern of annual $\mathrm{P}$, with the lowest values in 2003 and 2011 (Figure 2), which were 75\% of the average annual P from 2001 to 2013. DF estimates were higher in relatively wet years (2004 and 2010) for all sites, when annual $P$ was greater than $115 \%$ of the 2001 to 2013 mean.

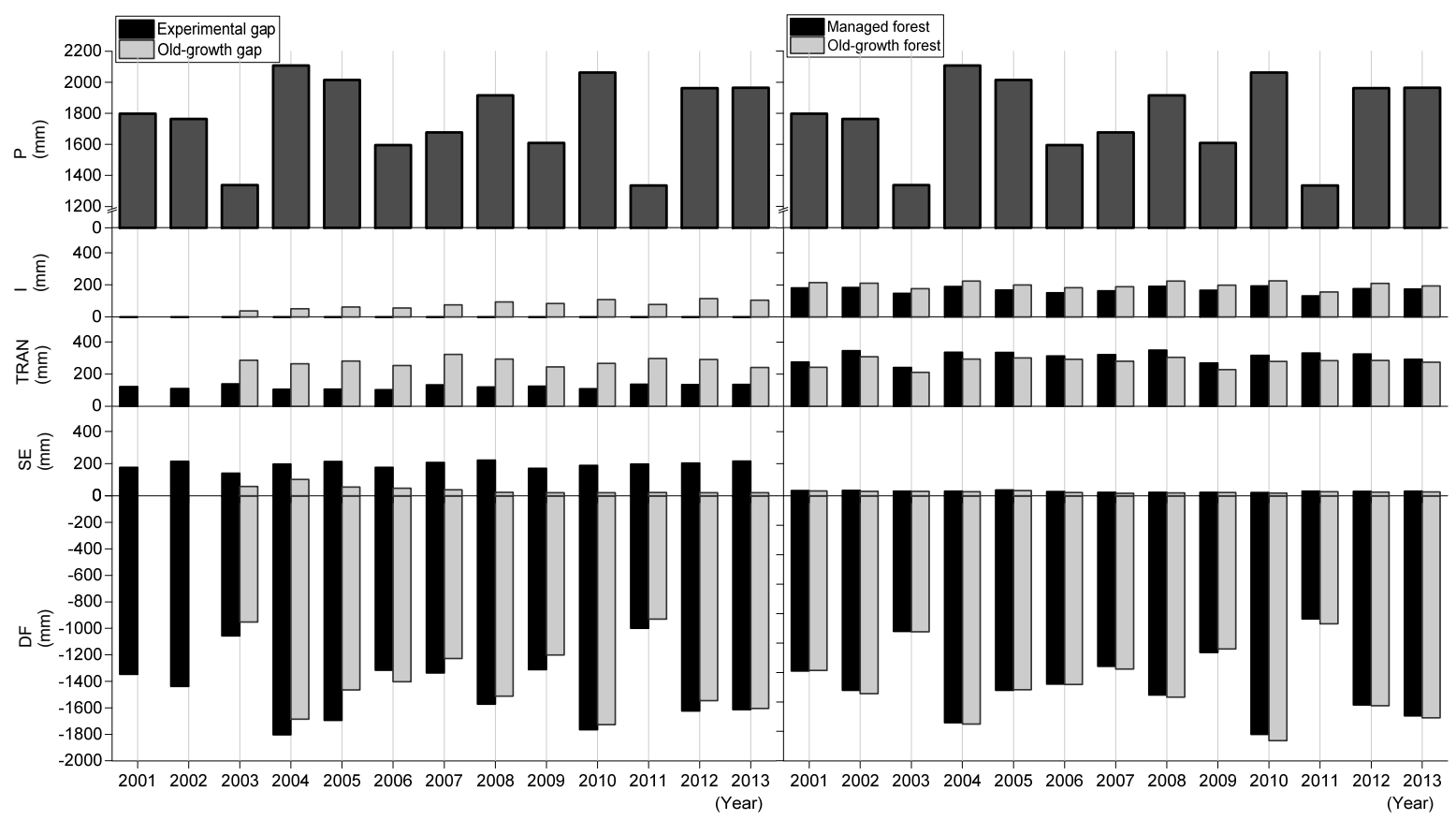

Figure 2. Annual precipitation (P), canopy interception (I), transpiration (TRAN), soil evaporation (SE), and drainage flux (DF) (mm) in gaps and forests in the Dinaric Karst from 2001 to 2013, except for the old-growth gap, for which the simulation ran from 2003 to 2013.

Annual DF estimates were highest in the experimental gap ( $81 \%$ of $\mathrm{P})$, followed by the old-growth gap ( $78 \%$ of $\mathrm{P})$, old-growth forest $(72 \%$ of $\mathrm{P})$, and managed forest $(71 \%$ of P) (Figure 3, Table 2). In the experimental gap, DF accounted for $1784 \mathrm{~mm}$ or $86 \%$ of $\mathrm{P}$ 
in wet years and $1028 \mathrm{~mm}$ or $77 \%$ of $\mathrm{P}$ in dry years. In contrast, in the old-growth gap, DF accounted for $1706 \mathrm{~mm}$ or $82 \%$ of $\mathrm{P}$ in wet years and $942 \mathrm{~mm}$ or $70 \%$ in dry years. Spearman correlation analysis showed that annual DF estimates for each of the four sites were significantly correlated $(R>0.918, p<0.001)$, although the correlation was highest in the old-growth and managed forest cases $(R=0.999, p<0.001)$. In wet years, DF accounted for $1581 \mathrm{~mm}$ or $76 \%$ of $\mathrm{P}$ in the managed forest and $1607 \mathrm{~mm}$ or $77 \%$ in the old-growth forest (Table 2), while in dry years it accounted for $878 \mathrm{~mm}(66 \%)$ and $896 \mathrm{~mm}(67 \%$ of P), respectively.

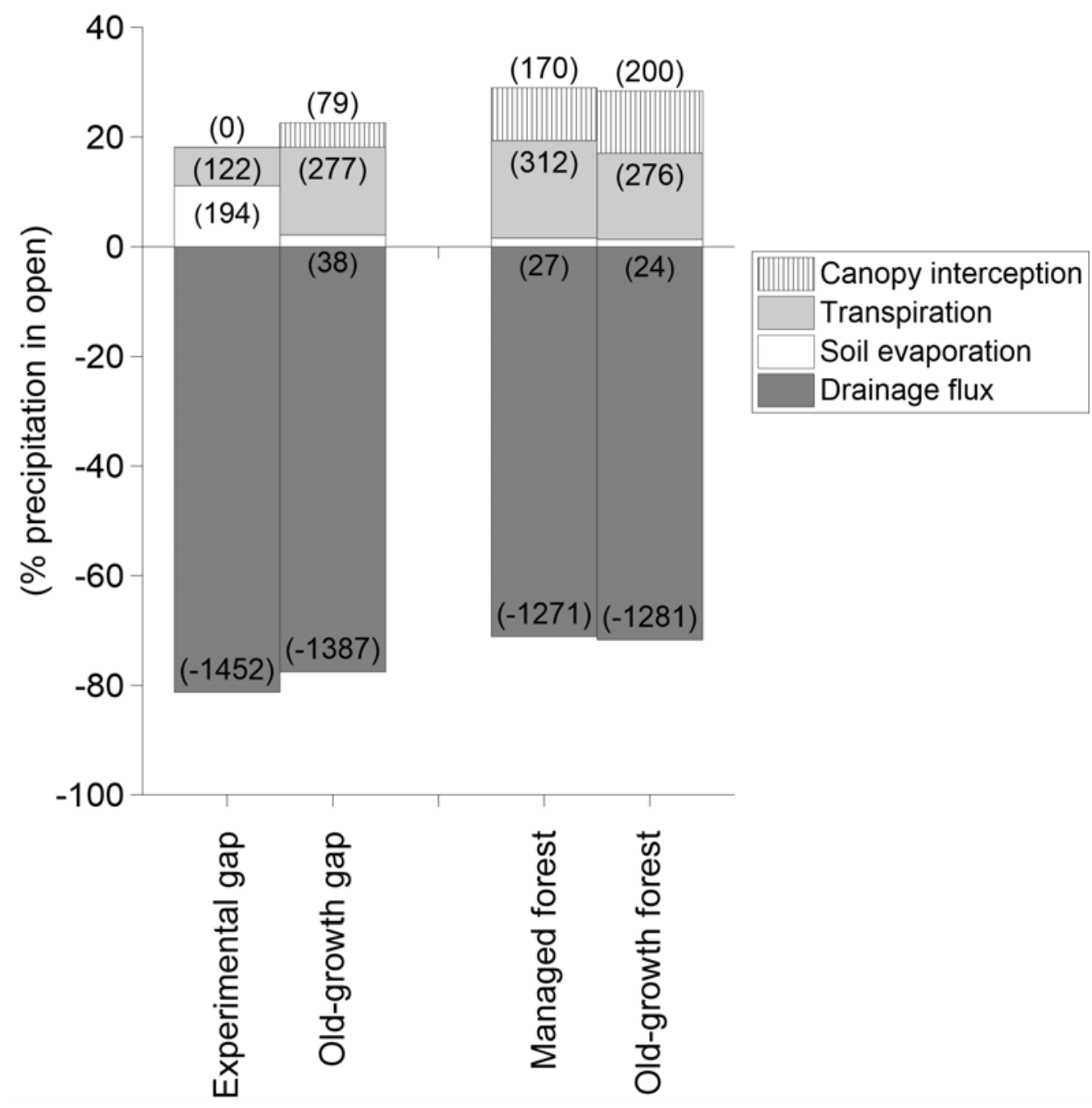

Figure 3. Mean annual canopy interception (I), transpiration (TRAN), soil evaporation (SE), and drainage flux (DF) (as \% of precipitation in the open; P) in gaps and forests in the Dinaric Karst. Figures in brackets are values in $\mathrm{mm}$. 


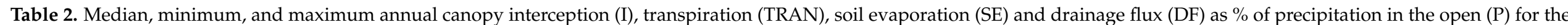
gaps and forests in the Dinaric Karst from 2001 to 2013 (for the old-growth gap from 2003 to 2013) and separately in wet years (2004, 2010), and dry years (2003, 2011).

\begin{tabular}{|c|c|c|c|c|c|c|c|c|c|c|c|c|c|}
\hline \multirow[t]{2}{*}{ Years } & \multirow[t]{2}{*}{ Indicator } & \multicolumn{3}{|c|}{ Experimental Gap } & \multicolumn{3}{|c|}{ Old-Growth Gap } & \multicolumn{3}{|c|}{ Managed Forest } & \multicolumn{3}{|c|}{ Old-Growth Forest } \\
\hline & & Mean & Min & Max & Mean & Min & Max & Mean & Min & Max & Mean & Min & $\operatorname{Max}$ \\
\hline \multirow{5}{*}{ 2001-2013 } & $\mathrm{DF}$ & 81 & 75 & 86 & 78 & 88 & 70 & 71 & 80 & 63 & 72 & 81 & 65 \\
\hline & SE & 11 & 9 & 15 & 2 & 1 & 5 & 2 & 1 & 2 & 1 & 1 & 2 \\
\hline & TRAN & 7 & 5 & 10 & 16 & 12 & 22 & 18 & 15 & 25 & 16 & 14 & 21 \\
\hline & I & 0 & 0 & 0 & 4 & 2 & 6 & 10 & 8 & 11 & 11 & 10 & 13 \\
\hline & $\mathrm{ETP}=\mathrm{SE}+\mathrm{TRAN}+\mathrm{I}$ & 18 & 14 & 25 & 23 & 19 & 30 & 29 & 25 & 37 & 28 & 25 & 35 \\
\hline \multirow{5}{*}{ Wet $(2004,2010)$} & $\mathrm{DF}$ & 86 & 86 & 86 & 82 & 84 & 80 & 76 & 73 & 79 & 77 & 74 & 81 \\
\hline & SE & 9 & 9 & 9 & 3 & 1 & 5 & 1 & 1 & 1 & 1 & 1 & 1 \\
\hline & TRAN & 5 & 5 & 5 & 13 & 13 & 13 & 16 & 15 & 16 & 14 & 14 & 14 \\
\hline & $\mathrm{I}$ & 0 & 0 & 0 & 4 & 2 & 5 & 9 & 9 & 9 & 11 & 11 & 11 \\
\hline & $\mathrm{ETP}=\mathrm{SE}+\mathrm{TRAN}+\mathrm{I}$ & 14 & 14 & 14 & 19 & 20 & 19 & 26 & 26 & 26 & 26 & 25 & 26 \\
\hline \multirow{5}{*}{ Dry $(2003,2011)$} & DF & 77 & 75 & 79 & 70 & 70 & 71 & 66 & 63 & 69 & 67 & 65 & 69 \\
\hline & SE & 13 & 11 & 15 & 3 & 2 & 4 & 2 & 2 & 2 & 2 & 2 & 2 \\
\hline & TRAN & 10 & 10 & 10 & 22 & 21 & 22 & 21 & 18 & 25 & 19 & 16 & 21 \\
\hline & $\mathrm{I}$ & 0 & 0 & 0 & 4 & 6 & 3 & 10 & 10 & 11 & 12 & 12 & 13 \\
\hline & $\mathrm{ETP}=\mathrm{SE}+\mathrm{TRAN}+\mathrm{I}$ & 25 & 21 & 21 & 29 & 29 & 30 & 34 & 31 & 37 & 33 & 31 & 35 \\
\hline
\end{tabular}


As expected, the experimental gap had significantly larger annual SE estimates (11\% of $\mathrm{P}$ ) compared to the forests ( $2 \%$ of $\mathrm{P}$ in the managed and $1 \%$ in the old-growth forest) and the old-growth gap $(2 \%$ of $\mathrm{P})(p<0.001)$. For the old-growth gap, a statistically significant decrease in SE was shown during the simulation period $(\mathrm{SE}=-6.33 \times$ year $+12,743$, $\mathrm{N}=11, R^{2}=0.645$ ) due to shading of progressive natural tree regeneration. Statistical tests showed that annual SE estimates were significantly correlated only in the case of managed and old-growth forests $(R=0.975, p<0.001)$. In dry years, the experimental gap and both forests had greater SE (170 $\mathrm{mm}$ or $13 \%$ of $P$ in the experimental gap and $27 \mathrm{~mm}$ and $29 \mathrm{~mm}$ or $2 \%$ in both forests) than in wet years (193 $\mathrm{mm}$ or $9 \%$ of $\mathrm{P}$ in the experimental gap and $21 \mathrm{~mm}$ and $254 \mathrm{~mm}$ or $1 \%$ in both forests). SE in the old-growth gap was $60 \mathrm{~mm}$ in wet and $39 \mathrm{~mm}$ in dry years, accounting for $3 \%$ of $\mathrm{P}$.

Annual estimates of TRAN were significantly lower in the experimental gap ( $7 \%$ of P) compared to the other sites $(p<0.001)$. TRAN accounted for $18 \%$ of $\mathrm{P}$ in the managed and $16 \%$ in the old-growth forest and gap. Annual TRAN estimates for forests and gaps showed no significant temporal trend and were significantly correlated only in the case of managed and old-growth forests $(R=0.929, p<0.001)$. In wet years, TRAN was much lower than in dry years at all sites, accounting for $107 \mathrm{~mm}$ or $5 \%$ of $P$ in the experimental gap and $266 \mathrm{~mm}$ or $13 \%$ of $P$ in the old-growth gap. In dry years, TRAN accounted for $138 \mathrm{~mm}$ or $10 \%$ of $\mathrm{P}$ in the experimental gap and $292 \mathrm{~mm}$ or $22 \%$ in the old-growth gap. In contrast, TRAN accounted for $327 \mathrm{~mm}$ or $16 \%$ of $P$ in managed forest and $287 \mathrm{~mm}$ or $14 \%$ in old-growth forest in wet years, while in dry years TRAN accounted for $287 \mathrm{~mm}$ or $21 \%$ of $\mathrm{P}$ in the managed forest and $248 \mathrm{~mm}$ or $19 \%$ in the old-growth forest.

Annual I estimates differed significantly among the four sites $(p<0.001)$ and were higher in the forests than in the gaps, as expected due to the presence of tall trees in the forests. I was highest in the old-growth forest $(11 \%$ of $P)$, followed by the managed forest $(10 \%)$, and was significantly correlated in the case of both forest sites $(R=0.972$, $p<0.001)$. In the old-growth gap annual I estimates accounted for $4 \%$ of $P$ and statistically significantly increased during the simulation period $(I=6.77 \times$ year $-13510, N=11$, $R^{2}=0.802$ ). Annual I estimates in the experimental gap were close to $0 \mathrm{~mm}$ in dry and wet years, as expected from the sparce ground vegetation that reached only $0.5 \mathrm{~m}$ in height 12 years after gap formation. In contrast, in forests, I estimates showed only a small increase in wet years compared to dry years, from $139 \mathrm{~mm}(10 \%$ of P) to $192 \mathrm{~mm}(9 \%$ of $\mathrm{P})$ in the managed forest and from $166 \mathrm{~mm}(12 \%$ of P) to $224 \mathrm{~mm}(11 \%$ of P) in the old-growth forest.

The lowest water regulation capacity was present in the experimental gap, where annual DF was highest ( $81 \%$ of P) and the sum of annual I, TRAN, and SE referred to as ecosystem evapotranspiration (ETP), accounted for $18 \%$ of P. In wet years, DF was $756 \mathrm{~mm}$ or relative to P 9\% higher and ETP was $7 \mathrm{~mm}$ or relative to P 9\% lower in the experimental gap than in dry years. This was followed by the old-growth gap, where annual DF was $78 \%$ of $\mathrm{P}$ and annual ETP was $23 \%$ of P. In wet years, DF was $764 \mathrm{~mm}$ or $12 \%$ of P higher and ETP was $17 \mathrm{~mm}$ or $10 \%$ of P lower in the old-growth gap than in dry years. Water regulation capacity was highest and generally similar for both forests. Annual DF estimates were only $1 \%$ of $P$ higher in old-growth compared to managed forest and were $180 \mathrm{~mm}$ or $10 \%$ of $\mathrm{P}$ higher in wet years compared to dry years in both forests. In addition, annual ETP estimates were lower by $1 \%$ of $\mathrm{P}$ in the old-growth forest compared to the managed forest. ETP was lower in wet years compared to dry years in both forests, with a difference of $89 \mathrm{~mm}$ or $8 \%$ of $\mathrm{P}$ in the managed forest and $92 \mathrm{~mm}$ or $7 \%$ of $\mathrm{P}$ in the old-growth forest.

\section{Discussion}

The results of this study indicate that the water retention capacity of the vegetation and soil in the large experimental gap was significantly lower compared to a gap in a nearby old-growth forest. The formation of a large experimental gap with a diameter greater than the height of the surrounding forest caused unfavorable environmental conditions that hindered successful natural tree regeneration for a long time [47]. The interception surfaces were unable to recover quickly after gap formation due to colonization by grasses 
and forest understory that benefit from high irradiance and nutrient leaching from the soils $[15,89,90]$. This was not the case in the irregularly shaped old-growth gap, where patches with different development phases, including dense natural beech regeneration were present. Studies in small- and medium-sized experimental gaps also reported dense natural tree regeneration as early as four years after gap formation [47], with hydrologic fluxes comparable to those in the old-growth gap [49].

Knowledge of water regulation ES of forests is a highly relevant goal of forest management to ensure multifunctionality and climate resilience [91-93]. Furthermore, disturbances associated with human activities and natural processes can have widespread and long-lasting impacts on hydrological, landscape, and ecosystem processes [94]. Reduced evapotranspiration in large canopy gaps will tend to increase drainage flux and contribute to reduced water retention capacity, as demonstrated in our study. The Brook90 model estimated that $71-72 \%$ of annual precipitation (1271 to $1281 \mathrm{~mm}$ ) drained from the forest to the subsurface. In the experimental gap, almost all precipitation falls directly on the ground vegetation cover or soil, which havea smaller interception surface than the multilayered mixed foliage of fir-beech forests [31]. Accordingly, drainage accounted for up to $81 \%$ of annual precipitation $(1452 \mathrm{~mm})$ in the large experimental gap, indicating a long-lasting reduction in water retention capacity even 12 years after formation. The higher drainage flux estimates for the gaps compared to the two forests in our study are explained by the lower water use by vegetation in the gaps compared to forests $[16,95]$. In addition, the water holding capacity of the gap root zones is lower compared to forests [37]. Gap formation also increased water drainage in a mixed forest in Germany [16], in a European beech forest in Austrian Kalkalpen [96], and in a pure European beech forest in Denmark [89]. For the mixed forest in Germany, the difference in soil water content between forest and gap was due to lower canopy interception in the gap [16], while for the beech-dominated Danish forest it was found that the main cause of differences in soil water content between forest and gap conditions was the lack of transpiration in the gap [97]. In addition, the progressive growth of natural tree regeneration and edge trees resulted in increased canopy interception and water extraction by roots, which could modify the gap effect as early as the second year after gap formation to reach forest conditions (ibid.). This is consistent with the results of our study, in which patches with different development phases, including remnants of standing decaying trees and the progressive growth of natural tree regeneration in the old-growth gap [98], contributed to lower drainage flux (78\% of annual precipitation or $1387 \mathrm{~mm}$ ) than in the large experimental gap. Moreover, drainage flux in wet years was $82 \%$ of annual precipitation $(1706 \mathrm{~mm}$ ) in the old-growth gap, while in dry years drainage flux was only $70 \%$ (942 $\mathrm{mm}$ ), indicating a higher water retention capacity compared to the large experimental gap. Katzensteiner [27] also reported lower drainage values for beech regeneration (85\% and 75\% of seasonal precipitation in 1996 and 1997, respectively) compared to canopy gaps (90\% and $81 \%$ of seasonal precipitation in 1996 and 1997, respectively). Nevertheless, small and medium-sized canopy gaps in fir-beech forests with diameters smaller than the height of the surrounding forest ensure suitable conditions for successful establishment of natural tree regeneration as early as four years after canopy gap formation [47], resulting in similar drainage fluxes and evapotranspiration estimates as in the old-growth gap [49].

Differences in water retention capacity between experimental and old-growth gaps were exacerbated in the dry years of 2003 and 2011 when extreme drought led to widespread disturbances in European forest ecosystems [83-87]. The annual P measured at the nearest meteorological station was 30\% lower than the long-term P (1971-2000) in 2003 and 22\% lower in 2011. Drainage flux in the large experimental gap accounted for $77 \%$ of annual precipitation $(1028 \mathrm{~mm})$ in dry years, while it accounted for only $70 \%(942 \mathrm{~mm})$ in the old-growth gap. Soil evaporation was $10 \%$ of $P$ higher in the experimental gap than in the old-growth gap, while transpiration and interception were higher in the old-growth gap, as expected. Observed records and climate simulations of some meteorological variables (e.g., temperature, evapotranspiration) [99] and shifts in precipitation patterns [100] show 
increasing trends in the intensity, duration, severity, and spatial extent of droughts worldwide [101]. The Dinaric Karst region has also experienced multiple severe and prolonged droughts over the last century, which, together with secondary insect damage, have led to episodes of forest decline [102]. This should be considered when developing forest management strategies for climate change adaptation [103,104].

Water regulation capacity of managed forest and old-growth forest was generally similar and higher compared to both gaps. In the managed forest with the currently practiced traditional shelterwood management system, annual drainage flux was $71 \%$ of annual precipitation $(1271 \mathrm{~mm})$ and $72 \%(1281 \mathrm{~mm})$ in the old-growth forest, while evapotranspiration was $29 \%$ of annual precipitation $(510 \mathrm{~mm})$ in the managed forest and $28 \%(500 \mathrm{~mm})$ in the old-growth forest. Estimated values of the drainage flux for the forests were similar to those reported by Katzensteiner [27] for a European beech forest in Austrian Kalkalpen, with drainage flux values corresponding to $75 \%$ and $65 \%$ of growing season precipitation in 1996 and 1997, respectively. In wet years, drainage flux was 10\% of annual precipitation higher and evapotranspiration 7\% (managed forest) and $8 \%$ (old-growth forest) of annual precipitation lower in both forests than in dry years.

\section{Conclusions}

In fir-beech forests in the Dinaric Karst, the loss of leaf area due to large canopy gap formation significantly reduces the water storage capacity of soil and vegetation over the long term. The unfavorable environmental conditions for natural tree regeneration even 12 years after the formation of the experimental gap resulted in lower evapotranspiration and higher drainage flux compared to a gap in a nearby old-growth forest. Patches of different development phases, including remnants of standing decaying trees and progressive growth of natural tree regeneration in the old-growth gap showed higher transpiration and canopy interception, and lower soil evaporation and drainage flux compared to the large experimental gap.

For optimal provision of water regulation ES of forests in the Dinaric Karst, continuous cover forestry should be promoted, emphasizing the size and shape of canopy gaps as a critical factor for successful natural tree regeneration. Small, irregularly shaped canopy gaps no larger than tree height should be created, mimicking the structural characteristics of naturally occurring gaps in old-growth forests.

Supplementary Materials: The following are available online at https:/ /www.mdpi.com/1999-490 7/12/2/224/s1, Table S1: Values for selected parameters used in the Brook90 model simulations; Figure S1: Monthly throughfall (mm) - measured values and simulated with the Brook90 model for (a) the experimental gap, (b) old-growth gap, (c) managed forest and (d) old-growth forest; Figure S2: Daily soil water contents (SWC, $\mathrm{mm})$ of the rooting depth $(0$ to $40 \mathrm{~cm})$-measured values and simulated with the Brook90 model for (a) experimental gap; (b) old-growth gap; (c) managed forest and (d) old-growth forest in the Dinaric Karst from 2001 to 2007, except for the old-growth gap from 2003 to 2007; Table S2: Linear regression $(y=a+b \times x)$ coefficients, linear correlation coefficient $(r)$, index of agreement (D), root mean square error (RMSE), and sample size (n) describing the goodness-of-fit between Brook90 model simulated (y) and measured (x) daily values for the soil water contents (0-40 $\mathrm{cm}$ layer) and monthly throughfall $(\mathrm{mm})$ for two calibration periods.

Funding: This research was funded by the Slovenian Research Agency within the project "Infiltration processes in forested karst aquifers under changing environment" (no. J2-1749) and the core funding for the Program Group “Forest biology, ecology and technology” (P4-0107).

Acknowledgments: We would like to express our gratitude to many experts from the Slovenian Forestry Institute. We are grateful to two anonymous referees and editors for their valuable comments and Jean Priscilla McCollister for proofreading and editing of the manuscript.

Conflicts of Interest: The author declares no conflict of interest. 


\section{References}

1. Kovačič, G.; Petrič, M.; Ravbar, N. Evaluation and Quantification of the Effects of Climate and Vegetation Cover Change on Karst Water Sources: Case Studies of Two Springs in South-Western Slovenia. Water 2020, 11, 3087. [CrossRef]

2. Costanza, R.; d'Arge, R.; de Groot, R.; Farber, S.; Grasso, M.; Hannon, B.; Limburg, K.; Naeem, S.; O’Neill, R.V.; Paruelo, J.; et al. The value of the world's ecosystem services and natural capital. Nature 1997, 387, 253-260. [CrossRef]

3. MEA. Ecosystems and Human Well-Being: Synthesis; World Resources Institute: Washington, DC, USA, $2005 ;$ p. 281.

4. Wallace, K.J. Classification of ecosystem services: Problems and solutions. Biol. Conserv. 2007, 139, 235-246. [CrossRef]

5. Guo, Z.; Gan, Y. Ecosystem function for water retention and forest ecosystem conservation in a watershed of the Yangtze River. Biodivers. Conserv. 2002, 11, 599-614. [CrossRef]

6. Guo, Z.; Xiao, X.; Li, D. An Assessment of Ecosystem Services: Water Flow Regulation and Hydroelectric Power Production. Ecol. Appl. 2000, 10, 925-936. [CrossRef]

7. Pilaš, I.; Feger, K.-H.; Vilhar, U.; Wahren, A. Multidimensionality of scales and approaches for forest-water interactions. In Forest Management and the Water Cycle: An Ecosystem-Based Approach; Bredemeier, M., Ed.; Springer: Dordrecht, The Netherlands, 2011; Volume 212, pp. 351-380.

8. Schüler, G. Identification of flood-generating forest areas and forestry measures for water retention. For. Snow Landsc. Res. 2006, 80, 99-114.

9. European Economic Area. Water-Retention Potential of Europe's Forests. A European Overview to Support Natural WaterRetention Measures. Available online: http://www.klimatilpasning.dk/media/966744/water-retention_potential_of_europes_ forests.pdf (accessed on 25 October 2016).

10. Hümann, M.; Schüler, G.; Müller, C.; Schneider, R.; Johst, M.; Caspari, T. Identification of runoff processes-The impact of different forest types and soil properties on runoff formation and floods. J. Hydrol. 2011, 409, 637-649. [CrossRef]

11. Bila, K. Are bark beetles responsible for droughts in the Šumava Mts.? A mini-review. Eur. J. Environ. Sci. 2016, 6, 108-113.

12. Zhang, M.; Liu, N.; Harper, R.; Li, Q.; Liu, K.; Wei, X.; Ning, D.; Hou, Y.; Liu, S. A global review on hydrological responses to forest change across multiple spatial scales: Importance of scale, climate, forest type and hydrological regime. J. Hydrol. 2017, 546, 44-59. [CrossRef]

13. Horvat, A.; Jeršič, T.; Papež, J. Varstvo pred hudourniki in erozijo ob vse intenzivnejših vremenskih ekstremih. Impact of climatic change on flood and erosion control. Ujma 2008, 22, 200-208.

14. Mina, M.; Bugmann, H.; Cordonnier, T.; Irauschek, F.; Klopcic, M.; Pardos, M.; Cailleret, M. Future ecosystem services from European mountain forests under climate change. J. Appl. Ecol. 2017, 54, 389-401. [CrossRef]

15. Ritter, E.; Vesterdal, L. Gap formation in Danish beech (Fagus sylvatica) forests of low management intensity: Soil moisture and nitrate in soil solution. Eur. J. For. Res. 2006, 125, 139-150. [CrossRef]

16. Zirlewagen, D.; von Wilpert, K. Modeling water and ion fluxes in a highly structured, mixed-species stand. For. Ecol. Manag. 2001, 143, 27-37. [CrossRef]

17. Petrič, M. Characteristics of Recharge-Discharge Relations in Karst Aquifer; Založba ZRC, Inštitut za Raziskovanje Krasa ZRC SAZU (Zbirka Carsologica): Postojna, Ljubljana, 2002; p. 154.

18. Petrič, M.; Kogovšek, J.; Ravbar, N. Effects of the vadose zone on groundwater flow and solute transport characteristics in mountainous karst aquifers-The case of the Javorniki-Snežnik massif (SW Slovenia). Acta Carsologica 2018, 47. [CrossRef]

19. Ford, E.D.; Williams, P.W. Karst Hydrogeology. In Karst Hydrogeology and Geomorphology; Wiley: Chichester, UK, 2007 ; pp. 103-144.

20. White, W.B.; Culver, D.C.; Herman, J.S.; Kane, T.C.; Mylroie, J.E. Karst Lands: The dissolution of carbonate rock produces unique landscapes and poses significant hydrological and environmental concerns. Am. Sci. 1995, 83, 450-459.

21. Sarrazin, F.; Hartmann, A.; Pianosi, F.; Rosolem, R.; Wagener, T. V2Karst V1.1: A parsimonious large-scale integrated vegetationrecharge model to simulate the impact of climate and land cover change in karst regions. Geosci. Model Dev. 2018, 11, 4933-4964. [CrossRef]

22. Janža, M.; Prestor, J. Ocena naravne ranljivosti vodonosnika v zaledju izvira Rižane po metodi SINTACS. Intrinsic vulnerability assessment of the aquifer in the Rižana spring chatcment by the method SINTACS. Geologija 2002, 45, 401-406. [CrossRef]

23. Ravbar, N.; Šebela, S. The effectiveness of protection policies and legislative framework with special regard to karst landscapes: Insights from Slovenia. Environ. Sci. Policy 2015, 51, 106-116. [CrossRef]

24. Stevanovic, Z.; Eftimi, R. Karstic sources of water supply for large consumers in Southeastern Europe-Sustainability, disputes and advantages. Geol. Croat. 2010, 63, 179-185. [CrossRef]

25. Duan, J.; Yang, J.; Tang, C.; Chen, L.; Liu, Y.; Wang, L. Effects of rainfall patterns and land cover on the subsurface flow generation of sloping Ferralsols in southern China. PLoS ONE 2017, 12, e0182706. [CrossRef] [PubMed]

26. Zou, Z.; Zeng, F.; Wang, K.; Zeng, Z.; Tang, H.; Zhang, H. Evaluation and Tradeoff Analysis of Ecosystem Service for Typical Land-Use Patterns in the Karst Region of Southwest China. Forests 2020, 11, 451. [CrossRef]

27. Katzensteiner, K. Effects of harvesting on nutrient leaching in a Norway spruce (Picea abies Karst.) ecosystem on a Lithic Leptosol in the Northern Limestone Alps. Plant Soil 2003, 250, 59-73. [CrossRef]

28. Urbančič, M.; Kutnar, L. Diversity of Soil Conditions and Ground Cover Vegetation in Forest on the Moraines of Pokljuka Plateau; Zbornik referatov Gorski gozd. XIX. Gozdarski študijski dnevi, Logarska dolina; Univerza v Ljubljani, Biotehniska fakulteta, Oddelek za gozdarstvo in obnovljive gozdne vire: Logarska dolina, Slovenia, 1998; pp. 223-241. 
29. Bončina, A.; Diaci, J.; Gašperšič, F. Long-term changes in tree species composition in the Dinaric mountain forests of Slovenia. For. Chron. 2003, 79, 227-232. [CrossRef]

30. Matthews, J.D. Silvicultural Systems; Clarendon Press: Oxford, UK, 1999; p. 284.

31. Kermavnar, J.; Marinšek, A.; Eler, K.; Kutnar, L. Evaluating Short-Term Impacts of Forest Management and Microsite Conditions on Understory Vegetation in Temperate Fir-Beech Forests: Floristic, Ecological, and Trait-Based Perspective. Forests 2019, 10, 909. [CrossRef]

32. Nagel, T.A.; Svoboda, M.; Diaci, J. Regeneration patterns after intermediate wind disturbance in an old-growth Fagus-Abies forest in southeastern Slovenia. For. Ecol. Manag. 2006, 226, 268-278. [CrossRef]

33. Diaci, J.; Roženbergar, D.; Bončina, A. Natural forests in the temperate zone of Europe-Values and utilisation. In Proceedings of the International Conference of Interactions of Light and Regeneration in Slovenian Dinaric Alps: Patterns in Virgin and Managed Forests, Mukacheco, Ukraine, 13-17 October 2003; Commarmot, B., Ed.; Swiss Federal Research Institute WSL: Birmensdorf, Switzerland; Carpathian Biosphere Reserve: Rakhiv, Ukraine, 2005; pp. 154-160.

34. Knight, D.H.; Yavitt, J.B.; Joyce, G.D. Water and nitrogen outflow from lodgepole pine forest after two levels of tree mortality. For Ecol. Manag. 1991, 46, 215-225. [CrossRef]

35. Prescott, C.E. Effects of clearcutting and alternative silvicultural systems on rates of decomposition and nitrogen mineralization in a coastal montane coniferous forest. For. Ecol. Manag. 1997, 95, 253-260. [CrossRef]

36. Kermavnar, J.; Eler, K.; Marinšek, A.; Kutnar, L. Initial understory vegetation responses following different forest management intensities in Illyrian beech forests. Appl. Veg. Sci. 2019, 22, 48-60. [CrossRef]

37. Vilhar, U.; Starr, M.; Urbančič, M.; Smolej, I.; Simončič, P. Gap evapotranspiration and drainage fluxes in a managed and a virgin dinaric silver fir-beech forest in Slovenia: A modelling study. Eur. J. For. Res. 2005, 124, 165-175. [CrossRef]

38. Roženbergar, D.; Kolar, U.; Čater, M.; Diaci, J. Comparison of four methods for estimating relative solar radiation in managed and old-growth silver fir-beech forest. Dendrobiology 2011, 65, 73-82.

39. Vilhar, U.; Simončič, P.; Kajfež-Bogataj, L.; Katzensteiner, K.; Diaci, J. Mikroklimatske razmere v vrzelih in sestojih dinarskega jelovo-bukovega gozda. Microclimate conditions in gaps and mature stands of Dinaric silver fir-beech forests. ZbGL 2006, 81, 21-36.

40. Urbančič, M.; Simončič, P.; Čater, M. Impacts of gaps on humus forms in dinaric silver fir-beech (Omphalodo-Fagetum) and soil solution quality. Mitteil. ÖBG 2005, 72, 179-187.

41. Simončič, P.; Kalan, P.; Urbančič, M.; Vilhar, U. Soil properties in virgin and in managed dinaric fir-beech forests-Preliminary results. Mitt. Österr. Bodenkd. Ges. 2003, 69, 77-82.

42. Kutnar, L.; Urbančič, M. Vpliv rastiščnih in sestojnih razmer na pestrost tal in vegetacije v izbranih bukovih in jelovo-bukovih gozdovih na Kočevskem. Influence of site and stand conditions on diversity of soil and vegetation in selected beech and fir-beech forests in the Kočevje region. ZbGL 2006, 80, 3-30.

43. Grebenc, T.; Christensen, M.; Vilhar, U.; Čater, M.; Martin, P.M.; Simončič, P.; Kraigher, H. Response of ectomycorrhizal community structure to gap opening in natural and managed temperate beech-dominated forests. Can. J. For. Res. 2009, 39, 1375-1386. [CrossRef]

44. Železnik, P.; Vilhar, U.; Starr, M.; de Groot, M.; Kraigher, H. Fine root dynamics in Slovenian beech forests in relation to soil temperature and water availability. Trees 2015, 30, 375-384. [CrossRef]

45. Čater, M.; Diaci, J.; Roženbergar, D. Gap size and position influence variable response of Fagus sylvatica L. and Abies alba Mill. For. Ecol. Manag. 2014, 325, 128-135. [CrossRef]

46. Rozenbergar, D.; Diaci, J. Architecture of Fagus sylvatica regeneration improves over time in mixed old-growth and managed forests. For. Ecol. Manag. 2014, 318, 334-340. [CrossRef]

47. Vilhar, U.; Roženbergar, D.; Simončič, P.; Diaci, J. Variation in irradiance, soil features and regeneration patterns in experimental forest canopy gaps. Ann. For. Sci. 2015, 72, 253-266. [CrossRef]

48. Vilhar, U.; Starr, M.; Katzensteiner, K.; Simončič, P.; Kajfež-Bogataj, L.; Diaci, J. Modelling drainage fluxes in managed and natural forests in the Dinaric karst: A model comparison study. Eur. J. For. Res. 2010, 129, 729-740. [CrossRef]

49. Vilhar, U.; Simončič, P. Water status and drought stress after gap formation in managed and semi-natural silver fir-beech forests. Eur. J. For. Res. 2012, 131, 1381-1397. [CrossRef]

50. Vilhar, U. Comparison of drought stress indices in beech forests: A modelling study. iFor. Biogeosci. For. 2016, 9, 635-642. [CrossRef]

51. White, W.B. Geomorphology and Hydrology of Karst Terrains; Oxford University Press: Oxford, UK, 1988 ; p. 464.

52. Dasgupta, S.; Mohanty, B.P.; Köhne, J.M. Impacts of Juniper Vegetation and Karst Geology on Subsurface Flow Processes in the Edwards Plateau, Texas. Vadose Zone J. 2006, 5, 1076-1085. [CrossRef]

53. Heilman, J.; Litvak, M.E.; McInnes, K.J.; Kjelgaard, J.F.; Schwinning, S. Water-storage capacity controls energy partitioning and water use in karst ecosystems on the Edwards Plateau, Texas. Ecohydrology 2012, 7, 127-138. [CrossRef]

54. Ferlan, M.; Eler, K.; Simončič, P.; Batič, F.; Vodnik, D. Carbon and water flux patterns of a drought-prone mid-succession ecosystem developed on abandoned karst grassland. Agric. Ecosyst. Environ. 2016, 220, 152-163. [CrossRef]

55. Vodnik, D.; Gričar, J.; Lavrič, M.; Ferlan, M.; Hafner, P.; Eler, K. Anatomical and physiological adjustments of pubescent oak (Quercus pubescens Willd.) from two adjacent sub-Mediterranean ecosites. Environ. Exp. Bot. 2019, 165, 208-218. [CrossRef] 
56. Eilmann, B.; Weber, P.; Rigling, A.; Eckstein, D. Growth reactions of Pinus sylvestris L. and Quercus pubescens Willd. to drought years at a xeric site in Valais, Switzerland. Dendrochronologia 2006, 23, 121-132. [CrossRef]

57. Looker, N.; Martin, J.; Hoylman, Z.; Jencso, K.; Hu, J. Diurnal and seasonal coupling of conifer sap flow and vapour pressure deficit across topoclimatic gradients in a subalpine catchment. Ecohydrology 2018, 11, e1994. [CrossRef]

58. Chirino, E.; Bellot, J.; Sanchez, J.R. Daily sap flow rate as an indicator of drought avoidance mechanisms in five Mediterranean perennial species in semi-arid southeastern Spain. Trees-Struct. Funct. 2011, 25, 593-606. [CrossRef]

59. Vorobevskii, I.; Kronenberg, R.; Bernhofer, C. Global BROOK90 R Package: An Automatic Framework to Simulate the Water Balance at Any Location. Water 2020, 12, 2037. [CrossRef]

60. Federer, C.A.; Vorosmarthy, C.; Fekete, B. Sensitivity of Annual Evaporation to Soil and Root Properties in Two Models of Contrasting Complexity. J. Hydrometeorol. 2003, 4, 1276-1290. [CrossRef]

61. Van der Salm, C.; Reinds, G.; de Vries, W. Assessment of the water balance in European forests: A model study. WASP FOCUS 2004, 4, 175-190.

62. Paul, K.I.; Polglase, P.J.; O'Connell, A.M.; Carlyle, J.C.; Smethurst, P.J.; Khanna, P.K.; Worledge, D. Soil water under forests (SWUF): A model of water flow and soil water content under a range of forest types. For. Ecol. Manag. 2003, 182, $195-211$. [CrossRef]

63. Holst, J.; Grote, R.; Offermann, C.; Ferrio, J.P.; Gessler, A.; Mayer, H.; Rennenberg, H. Water fluxes within beech stands in complex terrain. Int. J. Biometeorol. 2010, 54, 23-36. [CrossRef]

64. Yanai, R.D.; Tokuchi, N.; Campbell, J.L.; Green, M.B.; Matsuzaki, E.; Laseter, S.N.; Brown, C.L.; Bailey, A.S.; Lyons, P.; Levine, C.R.; et al. Sources of uncertainty in estimating stream solute export from headwater catchments at three sites. Hydrol. Process. 2015, 29, 1793-1805. [CrossRef]

65. Staudt, K.; Serafimovich, A.; Siebicke, L.; Pyles, R.D.; Falge, E. Vertical structure of evapotranspiration at a forest site (a case study). Agric. For. Meteorol. 2011, 151, 709-729. [CrossRef]

66. Gabrovšek, F.; Knez, M.; Kogovšek, J.; Mihevc, A.; Mulec, J.; Perne, M.; Petrič, M.; Pipan, T.; Prelovšek, M.; Slabe, T.; et al. Development challenges in karst regions: Sustainable land use planning in the karst of Slovenia. Carbonates Evaporites 2011, 26, 365-380. [CrossRef]

67. Turpaud, P.; Zini, L.; Ravbar, N.; Cucchi, F.; Petrič, M.; Urbanc, J. Development of a Protocol for the Karst Water Source Protection Zoning: Application to the Classical Karst Region (NE Italy and SW Slovenia). Water Resour. Manag. 2018, 32, 1953-1968. [CrossRef]

68. Hartman, T. Hundred years of virgin forest conservation in Slovenia. In Virgin Forests and Forest Reserves in Central and Eastern European Countries; Diaci, J., Ed.; BF, Oddelek za Gozdarstvo: Ljubljana, Slovene, 1999; pp. 111-120.

69. Bončina, A.; Diaci, J. Contemporary research on regeneration patterns of Central European virgin forests with recommendation for future research. ZbGL 1998, 56, 33-53.

70. Kraigher, H.; Jurc, D.; Kalan, P.; Kutnar, L.; Levanič, T.; Rupel, M.; Smolej, I. Beech coarse woody debris characteristics in two virgin forest reserves in southern Slovenia. ZbGL 2002, 69, 91-134.

71. Clark, D.F.; Kneeshaw, D.D.; Burton, P.J.; Antos, J.A. Coarse woody debris in sub-boreal spruce forest of west-central British Columbia. Can. J. For. Res. 1998, 28, 284-290. [CrossRef]

72. Puncer, I. Dinarski jelovo-bukovi gozdovi na Kočevskem. Razprave 1980, 22, 161.

73. Pisek, R. Vpliv strukturnih posebnosti sestojev v gozdnih rezervatih na razvoj monitoringa gozdnih ekosistemov. Influence of Structural Particularities of Forest Stands in Reserves on Improvement of Forest Ecosystem Monitoring. Magistrsko delo. Master's Thesis, University of Ljubljana, Ljubljana, Slovene, 2010.

74. U.S. Food and Agriculture Organization. Guidelines for Soil Description; FAO: Rome, Italy, 2006; p. 98.

75. Wrold Reference Basefor Soil Resources. World Reference Base for Soil Resources 2006, First Update 2007; IUSS: Vienna, Austria; ISRIC: Wageningen, The Netherlands; FAO: Rome, Italy, 2007; p. 115.

76. Vilhar, U. C dynamic of a beech stand in SE Slovenia-First results of the GOTILWA+ model. In Carbon Dynamics in Natural Beech Forests; Simončič, P., Ed.; Studia Forestalia Slovenica. Gozdarski Inštitut Slovenije: Ljubljana, Slovene, 2008 ; Volume 128.

77. Federer, C.A. BROOK90 Manual: A Simulation Model for Evaporation, Soil Water and Streamflow, Version 3.1; USDA Forest Service: Durham, NH, USA, 1995; p. 40.

78. Hammel, K.; Kennel, M. Charakterisierung und Analyse der Wasserverfuegbarkeit und des Wasserhaushalts von Waldstandorten in Bayern mit dem Simulationsmodell BROOK90. Forstl. Forsch. München 2001, 185, 135.

79. Dirksen, C. Soil Physics Measurements; Catena Verl.: Reiskirchen, Germany, 1999; p. 154.

80. Vogel, T.; Gerke, H.H.; Zhang, R.; Van Genuchten, M.T. Modeling flow and transport in a two-dimensional dual-permeability system with spatially variable hydraulic properties. J. Hydrol. 2000, 238, 78-89. [CrossRef]

81. Shuttleworth, W.J.; Wallace, J.S. Evaporation from sparse crops-An energy combination theory. Quart. J. Royal Meteorol. Soc. 1985, 111, 839-855. [CrossRef]

82. Thompson, S.A. Hydrology for Water Management; Balkema: Rotterdam, The Netherlands, 1999; p. 476.

83. Granier, A.; Reichstein, M.; Breda, N.; Janssens, I.A.; Falge, E.; Ciais, P.; Gruenwald, T.; Aubineth, M.; Berbigier, P.; Bernhofer, C.; et al. Evidence for soil water control on carbon and water dynamics in European forests during the extremely dry year: 2003. Agric. For. Meteorol. 2007, 143, 123-145. [CrossRef] 
84. Nikolova, P.S.; Raspe, S.; Andersen, C.P.; Mainiero, R.; Blaschke, H.; Matyssek, R.; Häberle, K.-H. Effects of the extreme drought in 2003 on soil respiration in a mixed forest. Eur. J. For. Res. 2009, 128, 87-98. [CrossRef]

85. Sohn, J.A.; Gebhardt, T.; Ammer, C.; Bauhus, J.; Häberle, K.-H.; Matyssek, R.; Grams, T.E.E. Mitigation of drought by thinning: Short-term and long-term effects on growth and physiological performance of Norway spruce (Picea abies). For. Ecol. Manag. 2013, 308, 188-197. [CrossRef]

86. Ciais, P.; Reichstein, M.; Viovy, N.; Granier, A.; Ogée, J.; Allard, V.; Aubinet, M.; Buchmann, N.; Bernhofer, C.; Carrara, A.; et al. Europe-wide reduction in primary productivity caused by the heat and drought in 2003. Nature 2005, 437, 529-533. [CrossRef]

87. Mátyás, C.; Bozic, G.; Gömöry, D.; Ivankovic, M.; Rasztovits, E. Juvenile growth response of European beech (Fagus sylvatica L.) to sudden change of climatic environment in SE European trials. iFor. Biogeosci. For. 2009, 2, 213-220. [CrossRef]

88. Clarke, N.; Žlindra, D.; Ulrich, E.; Mosello, R.; Derome, J.; Derome, K.; König, N.; Lövblad, G.; Draaijers, G.P.J.; Hansen, K.; et al. Sampling and Analysis of Deposition. Manual Part XIV. In Manual on Methods and Criteria for Harmonized Sampling, Assessment, Monitoring and Analysis of the Effects of Air Pollution on Forests; United Nations Economic Commission for Europe Convention on Long-range Transboundary Air Pollution; ICP Forests: Hamburg, Germany, 2016; Volume Part XIV, p. 68.

89. Ritter, E.; Starr, M.; Vesterdal, L. Losses of nitrate from gaps of different sizes in a managed beech (Fagus sylvatica) forest. Can. J. For. Res. 2005, 35, 308-319. [CrossRef]

90. Muscolo, A.; Sidari, M.; Bagnato, S.; Mallamaci, C.; Mercurio, R. Gap size effects on above- and below-ground processes in a silver fir stand. Eur. J. For. Res. 2010, 129, 355-365. [CrossRef]

91. Jourdan, M.; Cordonnier, T.; Dreyfus, P.; Riond, C.; de Coligny, F.; Morin, X. Managing mixed stands can mitigate severe climate change impacts on ecosystem functioning. bioRxiv 2020, 1-51. [CrossRef]

92. Schwaiger, F.; Poschenrieder, W.; Biber, P.; Pretzsch, H. Species Mixing Regulation with Respect to Forest Ecosystem Service Provision. Forests 2018, 9, 632. [CrossRef]

93. Mina, M.; Martin-Benito, D.; Bugmann, H.; Cailleret, M. Forward modeling of tree-ring width improves simulation of forest growth responses to drought. Agric. For. Meteorol. 2016, 221, 13-33. [CrossRef]

94. Ebel, B.A.; Mirus, B.B. Disturbance hydrology: Challenges and opportunities. Hydrol. Process. 2014, 28, 5140-5148. [CrossRef]

95. Cognard-Plancq, A.-L.; Marc, V.; Didon-Lescot, J.-F.; Norman, M. The role of forest cover on streamflow down sub-Mediterranean mountain watersheds: A modelling approach. J. Hydrol. 2001, 254, 229-243. [CrossRef]

96. Katzensteiner, K. Wasser- und Stoffhauhalt von Waldeokosystemen in den noerdlichen Kalkalpen; Universitaet fuer Bodenkultur: Wien, Austria, 2000; Volume 15, p. 159.

97. Ritter, E.; Dalsgaard, L.; Einhorn, K.S. Light, temperature and soil moisture regimes following gap formation in a semi-natural beech-dominated forest in Denmark. For. Ecol. Manag. 2005, 206, 15-33. [CrossRef]

98. Diaci, J.; Adamic, T.; Rozman, A. Gap recruitment and partitioning in an old-growth beech forest of the Dinaric Mountains: Influences of light regime, herb competition and browsing. For. Ecol. Manag. 2012, 285, 20-28. [CrossRef]

99. Intergovernmental Panel on Climate Change. Climate Change 2007: The Physical Science Basis.Contribution of Working Group I to the Fourth Assessment Report of the Intergovernmental Panel on Climate Change; Cambridge University Press: Cambridge, UK; New York, NY, USA, 2007; p. 996.

100. Luis, M.; Čufar, K.; Saz, M.; Longares, L.; Ceglar, A.; Kajfež-Bogataj, L. Trends in seasonal precipitation and temperature in Slovenia during 1951-2007. Reg. Environ. Chang. 2012, 14, 1801-1810. [CrossRef]

101. Mishra, A.K.; Singh, V.P. A review of drought concepts. J. Hydrol. 2010, 391, 202-216. [CrossRef]

102. Nagel, T.A.; Mikac, S.; Dolinar, M.; Klopcic, M.; Keren, S.; Svoboda, M.; Diaci, J.; Boncina, A.; Paulic, V. The natural disturbance regime in forests of the Dinaric Mountains: A synthesis of evidence. For. Ecol. Manag. 2017, 388, 29-42. [CrossRef]

103. Kolström, M.; Lindner, M.; Vilén, T.; Maroschek, M.; Seidl, R.; Lexer, M.J.; Netherer, S.; Kremer, A.; Delzon, S.; Barbati, A.; et al. Reviewing the Science and Implementation of Climate Change Adaptation Measures in European Forestry. Forests 2011, 4, 961-982. [CrossRef]

104. Bergès, L.; Balandier, P. Revisiting the use of soil water budget assessment to predict site productivity of sessile oak (Quercus petraea Liebl.) in the perspective of climate change. Eur. J. For. Res. 2010, 129, 199-208. [CrossRef] 